\section{Uncommon Causes of Hemodynamic Instability During Myocardial Revascul- arization without Cardiopulmonary Bypass}

Luciana Moraes dos Santos, TSA, M.D., Maria José Carvalho Carmona, TSA, M.D., Silvia Minhye Kim, M.D., Ricardo Ribeiro Dias, M.D., José Otávio Costa Auler Jr, TSA, M.D.

\section{INTRODUCTION}

Myocardial revascularization (MR) without cardiopulmonary bypass (CB) has become more frequent, presenting good results when compared to the same procedure with CB. With the evolution of the surgical technique, such as the use of myocardial stabilizers, complete revascularization is currently possible in a greater number of cases. Temporary hemodynamic instability can develop as a consequence of myocardial ischemia or by manipulation of the heart to gain access to the wall of the ventricles in which anastomosis will be performed. Two cases of sudden hemodynamic instability during MR without CB immediately after partial clamping of the aorta for the proximal anastomosis of the grafts are reported.

\section{CASE REPORTS}

Case 1: A 57-year old female patient, $72 \mathrm{~kg}$, with insulindependent diabetes mellitus, hypertension, dyslipidemia, and unstable angina. Electrocardiogram showed $\mathrm{Q}$ waves in $\mathrm{V} 1$ and $\mathrm{V} 2$, and inversion of $\mathrm{T}$ waves from $\mathrm{V} 1$ to $\mathrm{V} 5$; coronary angiography revealed a $99 \%$ obstruction of the anterior descending artery (AD), 70\% obstruction of the first diagonal artery $\left(\mathrm{DI}_{1}\right), 90 \%$ obstruction of the right coronary artery (RCA), and $70 \%$ obstruction of the posterior descending artery (PDA), with the presence of grade III collaterals for AD. Echocardiogram showed left ventricular ejection fraction (LVEF) of $60 \%$ and diameter of the aorta of $2.8 \mathrm{~cm}$. Laboratorial exa$\mathrm{ms}$ were unremarkable. The patient was being treated with $120 \mathrm{mg}$ of propranolol, $60 \mathrm{mg}$ of isosorbide dinitrate, $100 \mathrm{mg}$ of amlodipine, and 5,000 IU of low-molecular weight heparin a day. After admission to the operating room, the patient was monitored with pulse oximeter, ECG on $D_{\|}$and $V_{5}$ derivations with continuous analysis of the ST segment, and invasive blood pressure using the radial artery. Ethomidate $15 \mathrm{mg}$, sufentanil $100 \mu \mathrm{g}$, and atracurium $100 \mathrm{mg}$ were used for induction; anesthesia was maintained with continuous infusion of $0.5 \mu \mathrm{g} \cdot \mathrm{kg}^{-1} \cdot \mathrm{min}^{-1}$ of sufentanil and inhalational $1 \%$ isoflurane. A catheter was inserted in the pulmonary artery and $4,000 \mathrm{~mL}$ of Ringer's lactate and $100 \mathrm{~mL}$ of $20 \%$ albumin were administered to optimize preload and maintain adequate urine output. It was assessed an intraoperative bleeding of $500 \mathrm{~mL}$. Dobutamine $2 \mu \mathrm{g} \cdot \mathrm{kg}^{-1} \cdot \mathrm{min}^{-1}$, and variable doses of sodium nitroprusside and nitroglycerin were used for hemodynamic optimization. After distal anastomoses were performed the surgeon performed lateral clamping of the aorta for the proximal anastomosis. At this moment a sudden reduction in blood pressure from 60 to $40 \mathrm{mmHg}$ associated with an increase in pulmonary pressure from 25 to $45 \mathrm{mmHg}$ and reduction in HR to $50 \mathrm{bpm}$ were observed. The surgeon was informed and he released the aortic clamping, which was followed by the recovery of the previous hemodynamic status. The aorta was clamped once more after a few minutes and the same hemodynamic instability was observed that required the release of the aortic clamping. The aorta was clamped a third time using the minimal area of aortic clamping necessary, which was successful allowing completion of the proximal anastomosis of the saphenous vein graft without hemodynamic instability. The remaining proximal grafts were anastomosed to this saphenous vein graft to avoid further aortic manipulation and hemodynamic instability. The postoperative evolution was uneventful.

Case 2: A 59-year old male patient, $78 \mathrm{~kg}$, former smoker, with type II diabetes mellitus, chronic obstructive pulmonary disease and renal failure that did not require dialysis (creatinine $1.8 \mathrm{mg} \cdot \mathrm{dL}^{-1}$ ) who had angina pectoris with important left ventricular dysfunction and class II heart failure (NYHA) and an episode of cardiac arrest with ventricular fibrillation 10 months before the current admission. The ECG showed an inactive are in the inferior leads, and echocardiography showed a LVEF of $24 \%$ that was $15 \%$ on scintigraphy and $16 \%$ on magnetic resonance imaging. Coronary angiography showed $100 \%$ obstruction of the ostium of $A D$ and 95\% obstruction of the RCA with grade III collateral circulation. The patient underwent MR without $C B$ for anastomosis of the left internal mammary artery for the $A D$ artery, and saphenous vein for the posterior descending branch of the right coronary artery. During the surgery the patient was monitored with $E C G$ on $D_{\|}$and $V_{5}$ derivations with continuous analysis of the ST segment, invasive blood pressure through the radial artery, and insertion of a pulmonary artery catheter immediately after anesthetic induction, which was achieved with $20 \mathrm{mg}$ of ethomidate, $70 \mathrm{mg}$ of atracurium, and $30 \mu \mathrm{g}$ of sufentanil. Inhalational $1 \%$ isoflurane and $150 \mu \mathrm{g}$ of sufentanil were used for anesthesia maintenance. Ringer's lactate $2,500 \mathrm{~mL}$, and $20 \%$ albumin $100 \mathrm{~mL}$, were used for volume replacement. It was estimated an intraoperative bleeding of $100 \mathrm{~mL}$, with mean urine output of $60 \mathrm{~mL} \cdot \mathrm{h}^{-1}$. Continuous insulin infusion at a total dose of $7 \mathrm{IU}$ was used for intraoperative glycemic control. Dobutamine 2 to $3 \mu \mathrm{g} \cdot \mathrm{kg}^{-1} \cdot \mathrm{min}^{-1}$ and continuous infusion of variable doses of nitroglycerin were used for optimization of the cardiac output and to maintain blood pressure between 70 and $80 \mathrm{mmHg}$. After the distal anastomosis, tangential aortic clamping was performed for the proximal anastomosis that was immediately followed by a sudden drop in blood pressure from 60 to $48 \mathrm{mmHg}$ followed by hemodynamic instability. The clamp was removed and after hemodynamic stabilization a smaller segment of the aorta was clamped. Postoperatively, electrocardiographic changes or elevation of cardiac enzymes were not observed. 
However, the patient developed a high-output bronchopleural fistula secondary to the rupture of an emphysematous bleb. Thoracic and mediastinal drains were removed only on the eighth postoperative day. The patient presented good general status upon discharge.

\section{DISCUSSION}

Two cases of sudden hemodynamic instability during MR without CB shortly after partial clamping of the aorta for the proximal anastomoses of the grafts were reported. Urgent conversion to cardiopulmonary bypass was not necessary in either case, since early diagnosis of the clamping-related hemodynamic instability based on invasive monitoring and progressive reduction of the clamped area were adequate for clinical intraoperative control.

Myocardial revascularization without $C B$ has been frequently performed in several Cardiac Surgery centers worldwi$\mathrm{de}^{1}$. A recent metanalysis demonstrated that patients undergoing MR without $\mathrm{CB}$ have better outcomes after 30 days regarding the development of atrial fibrillation, need for inotropic drugs, respiratory infection, and need of blood transfusion, but without reduction in mortality, strokes, myocardial infarction, and renal failure when compared to patients undergoing surgical procedures with $\mathrm{CB}^{2}$. $\mathrm{Pa}$ tients with important comorbidities like renal failure, aortic calcification, peripheral arteriopathy, and cerebrovascular disease can benefit when CB can be avoided ${ }^{3}$. As the experience with the technique increases, the number of relative contraindications decreases ${ }^{4}$. It can be difficult to wean patients with left ventricular hypertrophy or poor ventricular function off $\mathrm{CB}$ due to low cardiac output syndrome, which contributes for the increase in surgical mortality, and, therefore, they are potential candidates for MR without $\mathrm{CB}^{3}$. The efficacy and safety of MR without $\mathrm{CB}$ have been demonstrated; besides decreasing extubation time in the immediate postoperative period ${ }^{5}$, this technique can reduce the costs of the procedure. Perioperative fast track approaches have become more common, but physiological limitations in the recovery of patients undergoing surgeries with $\mathrm{CB}$ can delay hospital discharge. In patients with low ejection fraction, $C B$ is an independent predictive factor for postoperative complications, such as the need for inotropic drugs or intra-aortic balloon pump ${ }^{6}$. On the other hand, MR without $C B$ can be associated with sudden and severe hemodynamic changes secondary to ischemia and heart positioning. Displacement of the heart to facilitate exposure of the arteries for the anastomosis can cause a reduction in cardiac output. Manipulation of a beating heart can cause important hemodynamic deterioration, justifying the use of invasive monitoring, including cardiac output and preload evaluation, especially in patients with preoperative ventricular dysfunction. The levels of mixed venous saturation can be a fast and indirect reflection of oxygen delivery, being useful during MR without $\mathrm{CB}$. Sudden and transitory hemodynamic instability can develop during displacement of the heart to access the arteries or with the use of the ventricular wall stabilizer (octopus). Initial treatment includes the increase in volume replacement, reevaluation of the position of the patient and lowering the head of the patient even more, adjustment of the afterload, and the use of inotropic drugs and vasopressors ${ }^{7}$.

During MR without $\mathrm{CB}$, partial and tangential clamping of the aorta, which is well tolerated in the presence of a beating heart, is performed to allow proximal anastomosis of the graft. At this moment, the anesthesiologist should reduce systemic blood pressure to decrease the risk of iatrogenic aortic injury. The presence of atheromatous plaques in the aorta is worrisome especially in the elderly due to the risk of embolization and consequent worsening of the postoperative neurologic prognosis. Ultrasound evaluation of the aorta before clamping can reduce the incidence of neurologic complications. It has been estimated that $25 \%$ of patients undergoing MR without $\mathrm{CB}$ have some contraindication to aortic manipulation ${ }^{8}$.

On the other hand, hemodynamic changes related with proximal anastomosis have been only poorly studied. Both cases presented here describe uncommon causes of hemodynamic instability developed after tangential clamping of the aorta. In the first case, the patient had normal ventricular function and the diameter of the aorta was $2.8 \mathrm{~cm}$, considered the lower limit of normalcy. Reduction of this diameter probably increased afterload enough to affect left ventricular function, resulting on a decrease in cardiac output and increase in pulmonary artery pressure, which was identified immediately by monitoring the pulmonary artery catheter, without which the diagnosis of hypotension might have been incorrect. In the second case, the patient presented preoperative left ventricular dysfunction, but he remained hemodynamically stable until the moment of the tangential clamping of the aorta. With the elevation of the preload promoted by aortic clamping, hypotension and an increase in pulmonary artery pressure with reduction in cardiac output were observed. Tangential clamping of the aorta and the use of the proper drugs can help minimize afterload. Although in this case the increase in afterload was secondary to the clamping of the aorta in a patient with low ejection fraction, in the other patient the borderline aortic diameter might have been the cause of significant hemodynamic instability, demonstrating that proximal clamping can potentially cause important hemodynamic changes. Although the use of a pulmonary artery catheter is not associated with a reduction in morbidiy or mortality, its use can contribute to avoid perioperative complications.

Both cases reported here demonstrate that anesthesia for MR without CB has peculiarities that if not identified can lead to cardiovascular deterioration or the decision to use cardiopulmonary bypass. Adequate knowledge of possible adverse events and proper strategies to minimize them is essential. On the other hand, in those two cases of low cardiac output secondary to aortic clamping, the interaction between the anesthesia and surgical teams with strict clinical vigilance and adequate monitoring were fundamental for early diagnosis and treatment. 


\section{REFERÊNCIAS - REFERENCES}

1. Hart JC, Spooner TH, Pym J et al. A review of 1,582 consecutive octopus off-pump coronary bypass patients. Ann Thorac Surg 2000;70:1017-1020.

2. Cheng DC, Bainbridge D, Martin JE et al. Does off-pump coronary artery bypass reduce mortality, morbidity, and resource utilization when compared with conventional coronary artery bypass? A meta-analysis of randomized trials. Anesthesiology 2005;102:188-203.

3. Magee MJ, Jablonski KA, Stamou SC et al. Elimination of cardiopulmonary bypass improves early survival for multivessel coronary artery bypass patients. Ann Thorac Surg 2002;73:1196-1203.

4. Abu-Omar Y, Taggart DP. Off-pump coronary artery bypass grafting. Lancet 2002;360:327-330.

5. Lee JH, Capdeville M, Marsh D et al. Earlier recovery with beatingheart surgery: a comparison of 300 patients undergoing conventional versus off-pump coronary artery bypass graft surgery. J Cardiothor Vasc Anesth 2002;16:139-143.

6. Arom KV, Flavin TF, Emery RW et al. Is low ejection fraction safe for off-pump coronary bypass operation? Ann Thorac Surg 2000;70:1021-1025.

7. Grundeman PF, Borst C, van Herwaarden JA et al. Vertical displacement of the beating heart by the octopus tissue stabilizer: influence on coronary flow. Ann Thorac Surg 1998;65:1348-1352.

8. Shimokawa T, Minato N, Yamada N et al. Assessment of ascending aorta using epiaortic ultrasonography during off-pump coronary artery bypass grafting. Ann Thorac Surg 2002;74:2097-2100.

\section{RESUMEN}

Santos LM, Carmona MJC, Kim SM, Dia RR, Auler Jr JOC - Causas Poco Comunes de Inestabilidad Hemodinámica durante la Revascularización Miocárdica sin Circulación Extracorpórea.

JUSTIFICATIVA Y OBJETIVOS: La revascularización miocárdica $(R M)$ en pacientes con hipertrofia y/o disfunción ventricular, es a menudo realizada sin la utilización de la circulación extracorpórea (CEC), porque el destete de la CEC puede ser difícil en esos casos. El control intraoperatorio exige un ajuste hemodinámico estricto, y también puede ser eficaz, el uso del pinzamiento aórtico parcial para minimizar las alteraciones hemodinámicas. El objetivo fue relatar dos casos de inestabilidad hemodinámica durante la RM sin CEC, después del pinzamiento parcial de la aorta.

RELATO DE LOS CASOS: En el primer caso, la paciente del sexo femenino presentaba un diámetro aórtico ligeramente reducido $(2,8 \mathrm{~cm})$, y el segundo paciente presentaba una fracción de eyección ventricular izquierda (FEVI) de un $24 \%$ a la ecocardiografía. En los dos casos, observamos una importante hipotensión arterial y una elevación de la presión arterial pulmonar inmediatamente después del pinzamiento aórtico. Los equipos de cirugía recibieron el aviso y la inestabilidad hemodinámica de cada caso se resolvió después de la liberación del pinzamiento parcial de la aorta. Los pinzamientos posteriores se realizaron en una menor área aórtica y las anastomosis proximales se hicieron sin intercurrencias.

CONCLUSIONES: Aunque las causas más frecuentes de la inestabilidad hemodinámica durante la RM sin CEC se refieran a la manipulación de la posición cardiaca y a las alteraciones de la precarga ventricular, en esos casos, la hipotensión arterial y la hipertensión pulmonar se debieron probablemente, a la reducción del débito cardíaco secundario, al aumento de la poscarga en pacientes con un diámetro reducido relativo de la aorta, o a la disfunción ventricular todos inclusive con pinzamiento parcial. El adecuado monitoreo intraoperatorio y la inmediata corrección de las alteraciones hemodinámicas, pueden minimizar la morbimortalidad quirúrgica. 